\title{
The Application of Flame Atomic Absorption Spectrometry for Gold Determination in Some of Its Bearing Rocks
}

\author{
Hisham K. Fouad*, Randa M. Elrakaiby, Mohamed D. Hashim \\ Analytical Chemistry Department, Nuclear Materials Authority, Cairo, Egypt \\ Email: "hishamfouad66@hotmail.com
}

Received 28 February 2015; accepted 28 March 2015; published 31 March 2015

Copyright (C 2015 by authors and Scientific Research Publishing Inc.

This work is licensed under the Creative Commons Attribution International License (CC BY). http://creativecommons.org/licenses/by/4.0/

(c) (i) Open Access

\begin{abstract}
A developed method was designed for gold determination directly in organic medium in some sedimentary rocks (fine sandstone, carbonates), pyrite, serpentine and international standard gold sample (MA-1a) using flame atomic absorption spectroscopy (FAAS). Instrumental parameters; burner angle, fuel flow rate, band pass and burner height together with chemical parameters; different media, leaching and interference effect were optimized to improve gold determination. Selective leaching using a new mixture $\left(5 \% \mathrm{KCN}, 5 \% \mathrm{Na}_{2} \mathrm{~S}_{2} \mathrm{O}_{3}\right.$ and hydrogen peroxide) offered maximum leaching percentage of gold $(>99 \%)$ with minimal concentration of accompanying elements. Extraction parameters using methyl isobutyl ketone (MIBK) from $3 \mathrm{M} \mathrm{HCl}$ were optimized for more than 99\% gold extraction, followed by scrubbing using $0.1 \mathrm{M} \mathrm{HCl}$. Gold was determined directly in organic phase. Beer's law was obeyed from $0.01 \mu \mathrm{g} / \mathrm{ml}$ to $10 \mu \mathrm{g} / \mathrm{ml}$. Standard deviation (from 0.017 to 1.05 ) and percentage error (from $1.5 \%$ to $2.5 \%$ ) using the present developed AAS method were calculated.
\end{abstract}

\section{Keywords}

Gold, Determination, MIBK, Extraction, FAAS

\section{Introduction}

Gold belongs to the group of elements which occur on the Earth with very low natural abundances. Distribution of gold in most geological samples is not homogeneous; it occurs as either grains of native gold or an alloy of

\footnotetext{
${ }^{*}$ Corresponding author.
}

How to cite this paper: Fouad, H.K., Elrakaiby, R.M. and Hashim, M.D. (2015) The Application of Flame Atomic Absorption Spectrometry for Gold Determination in Some of Its Bearing Rocks. American Journal of Analytical Chemistry, 6, $411-421$. http://dx.doi.org/10.4236/ajac.2015.65040 
gold, silver, and copper, or is often associated with base metal, carbonate and sulfide minerals. Due to the importance of gold $\mathrm{Au}$ ) and its dwindling sources, the recovery of Au from the secondary sources was essential. It was reported that about $20 \%$ of all Au deposits have significant copper mineralization commonly associated with chalcopyrite and chalcocite in certain ores [1]. The increase in gold exploration has led to further development and refinement of methodologies for its determination in rocks, ores, and other geological materials [2]. Due to its very low concentration, the sample matrix may cause serious interferences during gold determination; therefore preconcentration and separation methods should be used to solve these problems and render more sensitive, accurate and interference free determination.

In sulphide minerals, as pyrite, due to the strong sulphur binding to these minerals, gold was extracted by pyrometallurgical or hydrometallurgical routes using chemical oxidation as roasting and aqueous dissolution. Roasting under oxidizing conditions was a high-energy consumer technology, with stringent environmental controls on the emission of gases.

Cyanide leaching was considered to be one of the most effective reagents [3], where it extracted gold in an alkaline medium, and although no oxidant other than air was generally applied, rather addition of an oxidant might be beneficial. The dissolution of gold by cyanide with gold solubilized as an anionic complex was expressed by the following equation:

$$
\mathrm{Au}+2 \mathrm{CN}^{-} \rightleftarrows \mathrm{Au}(\mathrm{CN})^{2-}+\mathrm{e}
$$

Thiosulphate leaching was more specific for gold than the conventional cyanidation, hence quenching the interference concentration of foreign ions, and thus high gold recovery was achieved. On the other hand, cyanide forms very stable complexes with most of the cations, thus increasing matrix with several interfering cations. Dissolution of gold with thiosulphate was expressed as follows:

$$
4 \mathrm{Au}+8 \mathrm{~S}_{2} \mathrm{O}_{3}^{2-}+\mathrm{O}_{2}+2 \mathrm{H}_{2} \mathrm{O} \rightarrow 4 \mathrm{Au}\left(\mathrm{S}_{2} \mathrm{O}_{3}\right)_{2}+4 \mathrm{OH}^{-}
$$

Many techniques were available for gold determination using either the classical methods, such as fire assay (FA) or modern instrumental methods such as flame atomic absorption spectrometry (FAAS) [4]-[7], graphite furnace atomic absorption spectrometry (GFAAS) [8], inductively coupled plasma atomic emission spectrometry (ICP-AES) [9], inductively coupled plasma mass spectrometry (ICP-MS) [10] [11] and neutron activation analysis (NAA) [12], where these techniques were coupled with solvent extraction, ion exchange, or coprecipitation methods, which gave reliable results even from rock matrix, rich in the interfering species especially iron, present in appreciable quantity in sulfide faces banded iron formations (SBIF) [13].

One of the known procedures for gold determination was its extraction with methyl isobutyl ketone (MIBK) [14]-[16]. A prerequisite for analysis of gold with MIBK [17] and its determination in graphite furnace was the previous precipitation of iron with ammonium hydroxide in order to eliminate interference effect on gold.

Little attention was given to solvent extraction of gold from alkaline cyanide solutions where technical literature indicated that only tertiary and quaternary amines were studied for extraction of gold from cyanide solution [18] [19]. It was found that gold extraction with quaternary amines was possible but stripping was difficult.

A method was elaborated for the determination of the content of gold in geological samples by atomic absorption spectrophotometry (AAS) in combination with the fire assay method. The lower detectable limit for gold was $0.005 \mathrm{~g} / \mathrm{t}$. The analysis for silver and gold showed good agreement with the results using fire assay method [20].

Methods based on inductively coupled plasmas as atomization and ionization sources were applied for the determination of gold in different samples. Moreover, enrichment of gold by generation of its volatile species by reaction with $\mathrm{NaBH}_{4}$ in acidic medium coupled to ICP-OES detection was developed [21].

In the present work, our investigation was aiming for gold determination by a more economic way which was not time-consuming and provided good reproducibility of results. A new selective leaching mixture of cyanidethiosulphate-hydrogen peroxide for gold from different types of its bearing rocks lowered greatly the concentrations of the accompanying deleterious interfering elements together with highest gold leaching percentage (>99\%), which facilitated efficient extraction using MIBK with minimum co-extracted interfering elements. By scrubbing the loaded organic phase, the interfering ions were washed away and gold was determined in the organic phase directly using flame atomic absorption spectroscopy. 


\section{Experimental}

\subsection{Apparatus}

Flame atomic absorption spectrometer model UNICAM 969 was used in the present work. The optimum conditions recommended for gold determination involved a wavelength of 2428 angstroms (242.8 nm), lamp current $10 \mathrm{~mA}$, slit width $100 \mathrm{~nm}$, acetylene pressure $0.9 \mathrm{~L} / \mathrm{min}$ and $0.5 \mathrm{~nm}$ band pass.

\subsection{Reagents}

Standard gold solution (1000 $\mu \mathrm{g} / \mathrm{ml}$ ) supplied from Merck (Germany), Potassium cyanide supplied from Riedel de Haën (Germany), Sodium thiosulphate $\left(\mathrm{NaS}_{2} \mathrm{O}_{3}\right)$, supplied from Sigma-Aldrich (USA), Hydrogen peroxide (Adwic) Egypt, Methyl isobutyl Ketone (MIBK) supplied from Panreac, EU, Hydrochloric acid, supplied from Scharlau, Spain were used in the present study.

\subsection{Construction of Calibration Curve of Gold in Organic MIBK}

Gold calibration was prepared by shaking $100 \mathrm{ml}$ of $100 \mu \mathrm{g} / \mathrm{ml} \mathrm{Au}$ in $3 \mathrm{M} \mathrm{HCl}$ with $100 \mathrm{ml}$ MIBK. Calibration standards were prepared from this stock solution and pure MIBK solvent for FAAS measurements. Beer's law was obeyed from $0.01 \mu \mathrm{g} / \mathrm{ml}$ till a maximum concentration of $10 \mu \mathrm{g} / \mathrm{ml}$.

\subsection{Laboratory Sampling Method}

After powdering the samples to 260 mesh and homogenization, each was spread to form a layer of uniform thickness. Square grids of approximately 2 square inches were made on this layer of sample using a clean spatula. To obtain the optimal sample weight of $10 \mathrm{~g}$ [13], small and uniform amounts of sample were scooped from each grid.

\subsection{Sample Preparation}

Different types of rock samples bearing different concentrations of gold were applied in the present work namely; sedimentary rocks (S1 and S2), fine sandstone (nearly siltstone) with high carbonate content, pyrite $\left(\mathrm{FeS}_{2}\right)$ with high iron concentration, serpentine (magnesium iron silicate) and international standard sample (MA-1a) supplied from the Canadian Reference Materials Project, Canada center for Mineral and Energy Technology (CANMET report CCRMP86-1E).

\section{Results and Discussion}

For successful development of the present studied method, several certified samples must be available to evaluate the efficacy of the method, unfortunately, there was a lack in the certified samples and this was overcome by analyzing several types of rocks bearing gold using the established accurate, but time consuming, fire assay method to be used as certified samples, Table 1.

Different instrumental and chemical parameters were studied to optimize an accurate and precise determination of gold in organic medium. The instrumental parameters studied include burner angle of observation, fuel flow rate, burner height and band pass. Chemical parameters include the effect of different media, mixture of a new leaching reagent for various rock types bearing gold [5\% (w/v) KCN, $5 \%(w / v) ~ \mathrm{Na}_{2} \mathrm{~S}_{2} \mathrm{O}_{3}$ and hydrogen pe-

Table 1. Concentration of gold in different geological samples using fire assay method.

\begin{tabular}{cc}
\hline Sample Type & Au Concentration (ppm) \\
\hline S1 & 4.9 \\
S2 & 1.2 \\
Pyrite & 3.6 \\
Serpentine & 0.7 \\
Ma-1a & 21.7 \\
\hline
\end{tabular}


roxide], optimization parameters for maximum extraction of gold for direct determination in organic phase such as the effect of $\mathrm{HCl}$ concentration of the aqueous medium, $\mathrm{A} / \mathrm{O}$ phase ratio, contact time and settling time were studied.

\subsection{Effect of Instrumental Parameters on Gold Concentration}

Different instrumental parameters were studied, unless stated otherwise, at the optimized instrumental conditions in the instruction manual of AAS; wavelength $242.8 \mathrm{~nm}, 0.9 \mathrm{~L} / \mathrm{min}$ fuel gas flow and $0.5 \mathrm{~nm}$ band pass.

\subsection{Effect of Burner Angle of Observation}

Different concentrations of gold (in the range of calibration curve) at various burner angles (from $0^{\circ}$ to $30^{\circ}$ ) were studied while the other instrumental parameters were kept constant. From the data gathered in Table 2, it was found that $0^{\circ}$ burner angle was the best for gold determination. This can be interpreted to that the beam emitted from the hollow cathode lamp $(\mathrm{HCl})$ passed through the whole flame aligned with the incident beam thus absorbed all atoms of the element of interest, otherwise any deviation from this angle makes the beam pass only through part of the flame, hence absorbing only part of the atoms, thus giving low concentration values.

\subsection{Effect of Fuel Flow Rate}

Gold was determined at different fuel flow rates at $0^{\circ}$ burner angle, $242.8 \mathrm{~nm}$ and $0.5 \mathrm{~nm}$ band pass. From data in Table 3, it was observed that the change in fuel flow rate was accompanied by a fluctuation in standard gold concentrations except at $0.8 \mathrm{~L} / \mathrm{min}$, hence this optimum fuel flow rate was recommended unlike that in the instruction manual of the AAS $(0.9 \mathrm{~L} / \mathrm{min})$. This may be due to the lower the gas flows, the more time was available for complete atomization of the whole aspirated sample in the flame, hence giving the true concentration of gold. Below $0.8 \mathrm{~L} / \mathrm{min}$ the flame characteristic was totally changed.

\subsection{Effect of Burner Height}

The change of burner height on gold concentrations at wavelength $242.8 \mathrm{~nm}, 0^{\circ}$ burner angle, $0.8 \mathrm{~L} / \mathrm{min}$ fuel flow rate and $0.5 \mathrm{~nm}$ band pass was studied. From Table 4, it was clear that the change in burner height has a

Table 2. Different concentrations of gold at different burner angles.

\begin{tabular}{cccccc}
\hline \multirow{2}{*}{ Concentration of $\mathrm{Au}(\mu \mathrm{g} / \mathrm{ml})$} & \multicolumn{4}{c}{ Burner Angle } & $30^{\circ}$ \\
\cline { 2 - 5 } & $0^{\circ}$ & $10^{\circ}$ & $20^{\circ}$ & 0.25 \\
1 & 0.39 & 0.32 & 0.28 & 0.33 \\
2 & 0.98 & 0.51 & 0.4 & 0.48 \\
4 & 1.95 & 0.94 & 0.61 & 0.81 \\
8 & 3.95 & 1.7 & 1.08 & 1.90 & 1.40 \\
\hline
\end{tabular}

Table 3. Effect of fuel flow rate on different concentrations of gold.

\begin{tabular}{|c|c|c|c|c|c|}
\hline \multirow{2}{*}{ Concentration of $\mathrm{Au}(\mu \mathrm{g} / \mathrm{ml})$} & \multicolumn{5}{|c|}{ Fuel Flow Rate (L/min.) } \\
\hline & 0.8 & 0.9 & 1.2 & 1.7 & 2.0 \\
\hline 0.4 & 0.39 & 0.51 & 0.63 & 0.68 & 0.61 \\
\hline 1 & 1.02 & 0.90 & 1.06 & 0.90 & 1.06 \\
\hline 2 & 1.98 & 1.90 & 1.90 & 1.90 & 1.90 \\
\hline 4 & 4.02 & 3.80 & 3.80 & 3.70 & 3.7 \\
\hline 8 & 7.97 & 7.50 & 7.40 & 7.30 & 7.30 \\
\hline
\end{tabular}


Table 4. Effect of burner height on different concentrations of gold.

\begin{tabular}{ccccccc}
\hline & \multicolumn{5}{c}{ Burner Height $(\mathrm{mm})$} \\
\cline { 2 - 6 } Concentration of $\mathrm{Au}(\mu \mathrm{g} / \mathrm{ml})$ & 15 & 20 & 25 & 28 & 30 \\
\hline 0.4 & 0.68 & 0.63 & 0.41 & 0.51 & 0.52 \\
1 & 1.30 & 1.36 & 0.99 & 0.90 & 1.20 & 2.06 \\
2 & 2.60 & 2.36 & 2.10 & 1.99 & 3.06 & 7.40 \\
\hline
\end{tabular}

significant effect on gold concentration. The accurate concentration values of gold were found at $25 \mathrm{~mm}$ height, where maximum absorption of gold atoms by the incident beam from HCL was observed, while at other burner heights low gold concentrations were recognized. At this effective burner height $(25 \mathrm{~mm})$, maximum population of gold atoms was absorbed by the incident light of HCL.

\subsection{Effect of Band Pass}

Variable band pass values on gold concentrations were studied at the previously optimized parameters. Table 5 showed a significant change of gold concentrations at various band pass values. A high resolution of the principle line from the adjacent lines occurred at $0.2 \mathrm{~nm}$ band pass [22], where this value was recommended for gold determination unlike $0.5 \mathrm{~nm}$ suggested by the instruction manual of AAS.

Table 6 summed up the studied optimized instrumental parameters compared to that given by the instruction manual of AAS. It was found that several instrumental parameters were optimized to give more accurate values, thus improving the determination of gold concentration than that given in the instruction manual of AAS.

\subsection{Effect of Chemical Parameters}

\subsubsection{Effect of Different Media}

The effect of different concentrations of mineral acids, aquaregia and cyanide on gold determination was studied while the previous optimized instrumental parameters were kept constant. From the gathered data in Table 7, it was observed that $3 \mathrm{M} \mathrm{HCl}, 0.05 \mathrm{M} \mathrm{HNO}_{3}, 0.1 \mathrm{M} \mathrm{H}_{2} \mathrm{SO}_{4}, 0.03: 0.01$ aquaregia and 0.02 to $0.04 \mathrm{M}$ cyanide were the optimum media for gold determination with accurate results.

\subsubsection{Leaching Procedures for Different Rock Samples}

All studied samples were powdered to 260 mesh size [13] where potassium (or sodium) cyanide (one of the leaching reagents) was used to quantitatively complex the gold and, in addition, provide a high concentration of readily ionized atoms to reduce the possibility of gold ionization [23]. It was found that the most stable complex of gold was formed with cyanide, having the highest stability constant value than the other leaching reagents [24]. A new leaching reagent mixture for gold from different rock types constituting a mixture of cyanide, thiosulphate with optimum stoichiometric ratio, and hydrogen peroxide was used in the present work. This mixture has double benefit; first the thiosulphate added has specific gold leaching than the other accompanying ions and this facilitates lesser cyanide quantity used for leaching gold, thus lowering leaching of other interfering ions. Hydrogen peroxide was preferably used due to its rare responsibility for analytical problems and for oxidizing monovalent gold to trivalent to be compatible for extraction with MIBK [25]. The cyanide leaching process was based on the following reaction:

$$
4 \mathrm{Au}+8 \mathrm{KCN}+2 \mathrm{H}_{2} \mathrm{O}+\mathrm{O}_{2} \rightarrow 4 \mathrm{AuCN} \cdot \mathrm{KCN}+4 \mathrm{KCN}+4 \mathrm{KOH}
$$

Several trials were performed for adequate stoichiometric ratio of leaching reagent where $5 \%(\mathrm{w} / \mathrm{v}) \mathrm{KCN}$ and $5 \%(\mathrm{w} / \mathrm{v})$ thiosulphate together with hydrogen peroxide as oxidizing agent were optimum for maximum leaching of gold together with the least concentrations of accompanying interfering elements specially iron, facilitating an efficient gold extraction with the least co-extracted interfering elements with gold. 
Table 5. Effect of band pass on different concentrations of gold.

\begin{tabular}{cccc}
\hline & & Band Pass $(\mathrm{nm})$ & \\
\cline { 2 - 4 } Concentration of $\mathrm{Au}(\mu \mathrm{g} / \mathrm{ml})$ & 0.2 & 0.5 & 0.55 \\
\cline { 2 - 4 } & 0.39 & 0.51 & 1.07 \\
2 & 1.02 & 0.9 & 1.20 \\
4 & 1.98 & 1.90 & 3.10 \\
\hline
\end{tabular}

Table 6. Comparison of studied physical parameters to that given in the instruction manual of AAS.

\begin{tabular}{ccc}
\hline Parameters & Present Study & Recommended in Instruction Manual of AAS \\
\hline Burner angle & $0^{\circ}$ & Not mentioned \\
Fuel flow rate & $0.8 \mathrm{~L} / \mathrm{min}$ & $0.9 \mathrm{~L} / \mathrm{min}$ \\
Burner height & $25 \mathrm{~mm}$ & Not mentioned \\
Band pass & $0.2 \mathrm{~nm}$ & $0.5 \mathrm{~nm}$ \\
\hline
\end{tabular}

Table 7. Effect of different media concentrations on $2 \mathrm{ppm}$ synthetic gold.

\begin{tabular}{|c|c|c|c|c|c|c|c|c|c|}
\hline $\begin{array}{l}\mathrm{HCl} \\
(\mathrm{M})\end{array}$ & $\begin{array}{l}\text { Conc of } A u \\
(\mu \mathrm{g} / \mathrm{ml})\end{array}$ & $\begin{array}{c}\mathrm{HNO}_{3} \\
\text { (M) }\end{array}$ & $\begin{array}{l}\text { Conc of } \mathrm{Au} \\
(\mu \mathrm{g} / \mathrm{ml})\end{array}$ & $\begin{array}{c}\mathrm{H}_{2} \mathrm{SO}_{4} \\
\text { (M) }\end{array}$ & $\begin{array}{l}\text { Conc of } \mathrm{Au} \\
(\mu \mathrm{g} / \mathrm{ml})\end{array}$ & $\begin{array}{c}\text { Aquaregia (M) } \\
\mathrm{HCl}: \mathrm{HNO}_{3}\end{array}$ & $\begin{array}{l}\text { Conc of } \mathrm{Au} \\
(\mu \mathrm{g} / \mathrm{ml})\end{array}$ & $\begin{array}{l}\text { Cyanide } \\
\text { (M) }\end{array}$ & $\begin{array}{l}\text { Conc of } \mathrm{Au} \\
(\mu \mathrm{g} / \mathrm{ml})\end{array}$ \\
\hline 0.1 & 1.83 & 0.05 & 1.99 & 0.1 & 1.93 & 0.03:0.01 & 1.96 & 0.01 & 1.93 \\
\hline 0.5 & 1.81 & 0.1 & 1.97 & 0.5 & 1.77 & 0.3:0.1 & 1.88 & 0.02 & 2.04 \\
\hline 1 & 1.83 & 0.5 & 1.88 & 1 & 1.64 & $1.5: 0.5$ & 1.84 & 0.03 & 1.99 \\
\hline 2 & 1.86 & 1 & 1.80 & 2 & 1.41 & $3: 1$ & 1.74 & 0.04 & 1.99 \\
\hline 3 & 1.98 & 2 & 1.79 & 4 & 0.09 & & & 0.06 & 1.80 \\
\hline 4 & 1.84 & 4 & 1.74 & & & & & & \\
\hline
\end{tabular}

\subsubsection{Leaching of Sedimentary Samples and Serpentine}

Sedimentary rocks (S1 and S2) were fine sandstone (nearly siltstone) with high carbonate content and gold concentrations $1.2 \mu \mathrm{g} / \mathrm{ml}$ and $5 \mu \mathrm{g} / \mathrm{ml}$ (analyzed using fire assay method) respectively. The samples constitute high concentrations of major oxides ${ }^{(30)}$ mainly iron $\left(9 \%\right.$ as $\left.\mathrm{Fe}_{2} \mathrm{O}_{3}\right)$, silica $71 \%$, alumina $5.3 \%$, and some trace elements such as $\mathrm{Cu} 50 \mathrm{ppm}$ and $\mathrm{Ag} 130 \mathrm{ppm}$. XRD showed that serpentine sample constitutes mainly quartz $\left(\mathrm{SiO}_{2}\right)$, dolomite $\left(\mathrm{CaMgCO}_{3}\right)$ and magnesite $\left(\mathrm{MgCO}_{3}\right)$. To $25 \mathrm{~g}$ of each sample a leaching reagent was added with continuous stirring. After reaction was terminated, excess of hydrogen peroxide (5 ml) was added to ensure complete oxidation and the final volume reached $350 \mathrm{ml}$. After filtration the concentration of iron was found to be $1 \mathrm{ppm}$ and $0.65 \mathrm{ppm}$ in S1 and S2 respectively, where this leaching lowered the concentration of $\mathrm{Fe}_{2} \mathrm{O}_{3}$ from $9 \%$ in the head sample to $0.8 \mathrm{ppm}$ and $0.65 \mathrm{ppm}$ thus facilitating selective extraction of gold with least co-extracted iron.

\subsubsection{Leaching of Pyrite Sample}

A pretreatment for pyrite $\left(\mathrm{FeS}_{2}\right.$ ) (one of sulphide minerals bearing gold) was a prerequisite where a roasting step was needed before gold leaching. The sample $(3.6 \mu \mathrm{g} / \mathrm{ml}$ gold, analyzed by fire assay technique, and $90.84 \%$ total iron) was disseminated in quartz vein. The majority of published papers rely on aquaregia leaching which was found to be unsatisfactory [26].

Direct cyanidation for sulphide minerals was incomplete because a large portion of the fine gold remained encapsulated within the host mineral and was never in contact with the cyanide solution thus lowering gold 
leaching. The presence of hydrogen peroxide, as oxidizing agent, with cyanide during leaching process was used for gold recovery from various gold ores. The pyrite oxidative dissolution rates would no longer increase with the increase in hydrogen peroxide concentration [27]. It was represented as follows:

$$
\mathrm{FeS}_{2}+7.5 \mathrm{H}_{2} \mathrm{O}_{2} \rightarrow \mathrm{Fe}^{3+}+2 \mathrm{SO}_{4}{ }^{2-}+\mathrm{H}^{+}+7 \mathrm{H}_{2} \mathrm{O}
$$

Mineralogists, studying gold ores resistant to direct cyanide attack, have reported that gold particles were sometimes coated with a layer consisting mainly of hydrated oxides of iron [28]. These coatings were chiefly found on gold particles present in iron/sulphide ores. When these coatings were removed with dilute hydrochloric acid, both acid and cyanide readily leached gold. On applying this treatment to the present studied pyrite sample, the result of gold value was not changed which meant it may not be the only reason for low gold concentration during determination.

Temperature has effective results on gold concentrations in sulphide minerals, where using direct leaching without a preliminary roasting resulted in low gold concentrations. Several explanations were given; first sulphides wasn't oxidized to sulphate during leaching, and free sulphur then separates out, collecting the gold and limited its leaching. Second, was the incomplete breakdown of the sulphides present in the samples before leaching. The optimum temperature stated for sulphide minerals was $650^{\circ} \mathrm{C}$ where above this temperature low gold assays was reported, owing to the partial volatilization of gold [29]. Sodium cyanide needed to leach the roasted samples was less than that for the non-roasted ones; beside, its consumption increased for samples roasted at lower temperatures [30].

After roasting the sample at $650^{\circ} \mathrm{C}$ for two hours, the leaching reagent was added to $25 \mathrm{~g}$ of the pyrite sample with solid to liquid ratio of 1:5 where the total volume after washing reached $250 \mathrm{ml}$. The concentration of iron (as $\mathrm{Fe}_{2} \mathrm{O}_{3}$ ) was found to be only $10 \mathrm{ppm}$ in the leached solution.

\subsubsection{Leaching of International Certified Sample MA-1a}

The concentration of iron (as $\mathrm{Fe}_{2} \mathrm{O}_{3}$ ) in the certified sample MA-1a was $5.34 \%$ with a relatively high concentration of gold $(21.7 \mu \mathrm{g} / \mathrm{ml})$. Due to this relatively high gold value, the weight taken was limited only to $2 \mathrm{~g}$. A 100 $\mathrm{ml}$ leaching solution was added to the solid sample where after washing and filtering the final volume of leach liquor reached $250 \mathrm{ml}$. The concentration of iron $\left(\mathrm{as}_{\mathrm{Fe}} \mathrm{O}_{3}\right)$ in the leach liquor was $0.5 \mathrm{ppm}$. Table 8 summarized the iron concentration in both the original and leached studied samples. From the data gathered it was found that the leaching process of different samples hindered greatly high concentrations of iron leached with gold.

\subsubsection{Effect of Interfering Elements}

The extraction of gold and its separation from other elements at an early stage on gold determination was studied. Those elements interfere during gold determination by AAS, so they must be washed (scrubbed) from the organic phase before gold determination. The tolerance concentration values of interfering elements such as iron, silver and copper on gold determination were studied [31]. Table 9 showed that iron has severe interfering effect on gold determination starting from 0.5ppm hence, direct determination of gold in the leach liquor was not recommended. This was due to the relatively strong absorption line of iron (242.4 nm) near the analytical line for gold $(242.8 \mathrm{~nm})$ suggesting the severe interference of iron to gold [32] where gold extraction for its accurate determination was a perquisite. On the other hand, copper and silver have no interfering effect on $2 \mathrm{ppm}$ gold. Both copper (2\%) and iron (40\%) have negligible effect on extraction of gold when present in the sample solu-

\begin{tabular}{ccc}
\hline Table 8. Concentrations of iron after leaching in different samples. & \\
\hline Sample ID & Concentration of $\mathrm{Fe}_{2} \mathrm{O}_{3}$ in original samples (\%) & Concentration of $\mathrm{Fe}_{2} \mathrm{O}_{3}$ in leached samples (ppm) \\
\hline Certified sample (MA-1a) & 5.34 & 0.50 \\
S1 (carbonate) & 9.00 & 0.80 \\
S3 (carbonate) & 8.50 & 0.65 \\
Pyrite (sulphide) & 90.8 & 10.0 \\
Serpentine (silicate) & 5.50 & 1.00 \\
\hline
\end{tabular}


Table 9. Effect of different accompanying elements on the determination of gold.

\begin{tabular}{|c|c|c|c|c|c|}
\hline \multicolumn{6}{|c|}{ Concentration of gold (2 ppm) } \\
\hline Conc. of Fe (ppm) & $\mathrm{Au}(\mathrm{ppm})$ & Conc. of $\mathrm{Cu}$ (ppm) & $\mathrm{Au}(\mathrm{ppm})$ & Conc. of Ag (ppm) & $\mathrm{Au}(\mathrm{ppm})$ \\
\hline 0.5 & 1.6 & 5 & 2.02 & 1 & 2.01 \\
\hline 1.0 & 1.2 & 25 & 2.05 & 2 & 2.02 \\
\hline 5 & 1.0 & 50 & 2.06 & 5 & 2.01 \\
\hline 10 & 0.85 & 100 & 2.05 & 10 & 2.0 \\
\hline 50 & 0.5 & & & & \\
\hline 100 & 0.2 & & & & \\
\hline
\end{tabular}

tion but were partially co-extracted with gold and interfered during its determination hence they were scrubbed from the loaded extract with dilute hydrochloric acid, after which gold was determined directly in the organic extract by AAS with good accuracy.

\subsubsection{Extraction of Gold from Different Leached Samples}

Little research reported for solvent extraction of gold directly from cyanide solution [18] [19]. The organic solvent employed in the present extracting process, therefore, should be difficult to pyrolyse, have low poison content, have high flash point and widely selective to gold extraction, where many authors favored methyl isobutyl ketone (MIBK) due to its excellent flame characteristics and its slight solubility in water (1.9 g per $100 \mathrm{ml}$ water) accordingly; it was used as an efficient solvent. Direct extraction gave very low gold concentrations. Gold (III) in the presence of sufficiently high chloride and bromide concentrations formed either $\mathrm{AuCl}_{4}$ or $\mathrm{AuBr}_{4} \mathrm{Com}$ plexes where MIBK extracted these complexes [18]. In chloride solutions, gold existed as anion complex $\left(\mathrm{AuCl}_{4}^{-}\right.$), where MIBK molecule, having oxygen-unpaired electrons, tended to unite with protons $\left(\mathrm{H}^{+}\right)$in acidic solution and reacts with $\mathrm{AuCl}_{4}^{-}$, hence extracted gold from hydrochloric acid medium [33].

After gold leaching from different rock samples, extraction by MIBK from hydrochloric acid medium as gold chloride $\left[\mathrm{AuCl}_{4}\right]^{-}$was studied. The leach liquor of $\mathrm{S} 1(0.35 \mathrm{ppm} \mathrm{Au})$ was optimized for different extraction factors such as hydrochloric acid concentration, aqueous to organic $(\mathrm{A} / \mathrm{O})$ phase ratio, and contact time were studied for maximum extraction of gold and its direct determination in organic phase.

In spite of the low concentrations of the leached accompanying interfering ions with gold in different leach liquors, specially iron (Table 8) and applying the optimum extraction parameters to extract gold from different leach liquors of rocks bearing gold, low gold results were obtained for direct determination of gold in the organic phase. This was due to the presence of interfering elements co-extracted with gold especially iron, thus scrubbing of the organic phase with $0.1 \mathrm{M} \mathrm{HCl} \mathrm{[28]} \mathrm{was} \mathrm{applied} \mathrm{to} \mathrm{get} \mathrm{rid} \mathrm{of} \mathrm{the} \mathrm{accompanying} \mathrm{interfering} \mathrm{elements}$ with gold before its determination.

\subsubsection{Effect of Hydrochloric Acid Concentration}

A $25 \mathrm{ml}$ of gold leach liquor was evaporated till near dryness then different $\mathrm{HCl}$ concentrations were added to attain final concentrations of $1 \mathrm{M}, 2 \mathrm{M}$ and $3 \mathrm{M}$. Extraction with MIBK was performed at A/O phase ratio of 5:1, contact time 5 minutes, and room temperature $\left(27^{\circ} \mathrm{C} \pm 2^{\circ} \mathrm{C}\right)$. Scrubbing was performed with $0.10 \mathrm{M} \mathrm{HCl}$, where Figure 1 showed that $3 \mathrm{M} \mathrm{HCl}$ recorded the highest extraction percentage of gold.

\subsubsection{Effect of Aqueous to Organic Phase Ratio (A/0)}

An aliquot of $5 \mathrm{ml}$ from the leach liquor was evaporated till near dryness then $3 \mathrm{M} \mathrm{HCl}$ (optimum molarity studied) was added. Different aqueous to organic phase ratios were studied for maximum extraction of gold in 3M $\mathrm{HCl}$, contact time 5 minutes at room temperature $\left(27^{\circ} \mathrm{C} \pm 2^{\circ} \mathrm{C}\right)$. Figure 2 recorded the highest extraction percentage of gold at 5:1 $\mathrm{A} / \mathrm{O}$ phase ratio.

\subsubsection{Effect of Contact Time}

Several aliquots of $5 \mathrm{ml}$ of the prepared leach liquor (in $3 \mathrm{M} \mathrm{HCl}$ ) were shaken with MIBK in an A/O phase ra- 




Figure 1. Effect of hydrochloric acid concentration on gold extraction.

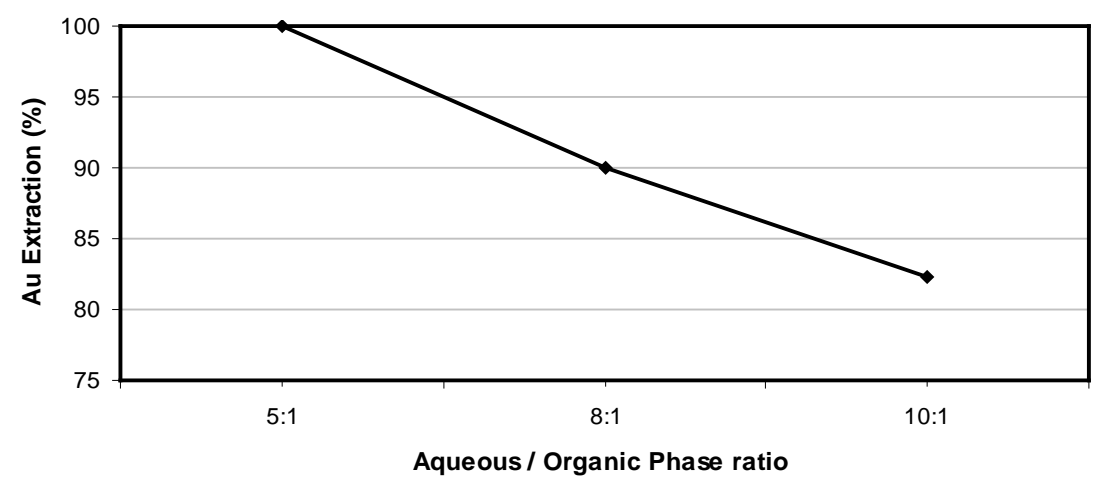

Figure 2. Effect of aqueous to organic phase ratio on gold extraction.

tio of 5:1, at different contact times and 5 minutes settling time. Extraction percentage of gold was calculated at each studied contact time. From Figure 3, it was found that maximum extraction of gold was attained after 5 minutes contact time.

\subsubsection{Effect of Settling Time}

An aliquot of $5 \mathrm{ml}$ of the prepared $3 \mathrm{M}$ chloride leach liquor was shaken with MIBK in an A/O phase ratio of $5: 1$, for 5 minutes. Optimum settling time for complete separation of both phases was found to be after 3 minutes.

By comparing the studied developed instrumental and chemical parameters for gold determination in leach liquors of different types of rocks bearing gold with that obtained using the fire assay method, it was found that close results for the two procedures was reached. Table 10 represented gold concentrations using the present developed method together with the fire assay method (considered as certified samples) for comparative study. From the statistical data calculated in Table 10 it was concluded that the present studied developed method gave statistically accepted results compared to fire assay method with a standard deviation ranged from 0.017 to 1.05 and a percentage error ranged from $1.5 \%$ to $3.0 \%$.

\section{Conclusion}

A developed method for gold determination in different types of its bearing rocks using flame atomic absorption (FAAS) was presented. Different instrumental and chemical parameters were optimized for accurate gold determination in organic phase. Several instrumental parameters were optimized, where $0^{\circ}$ burner angle of observation, $0.8 \mathrm{~L} / \mathrm{min}$ fuel flow rate, $25 \mathrm{~mm}$ burner height and $0.2 \mathrm{~nm}$ band pass were optimized for accurate gold determination. Several chemical parameters were studied where gold was determined accurately in $3 \mathrm{M} \mathrm{HCl}$, $0.05 \mathrm{M} \mathrm{HNO}_{3}, 0.03: 0.01 \mathrm{M}$ aquaregia and $0.02 \mathrm{M}$ to $0.04 \mathrm{M}$ cyanide media. A new leaching reagent mixture of $5 \% \mathrm{KCN}, 5 \%$ sodium thiosulphate $\left(\mathrm{NaS}_{2} \mathrm{O}_{3}\right)$ and $5 \mathrm{ml}$ hydrogen peroxide was used for maximum leaching of gold from its bearing rocks with minimum accompanying interfering elements. The effects of iron, copper and silver as interfering ions were studied on synthetic $2 \mathrm{ppm}$ gold. A $0.5 \mathrm{ppm}$ iron started to interfere while copper and silver have no interfering effect till $100 \mathrm{ppm}$ and $10 \mathrm{ppm}$ respectively. Optimum extraction parameters 


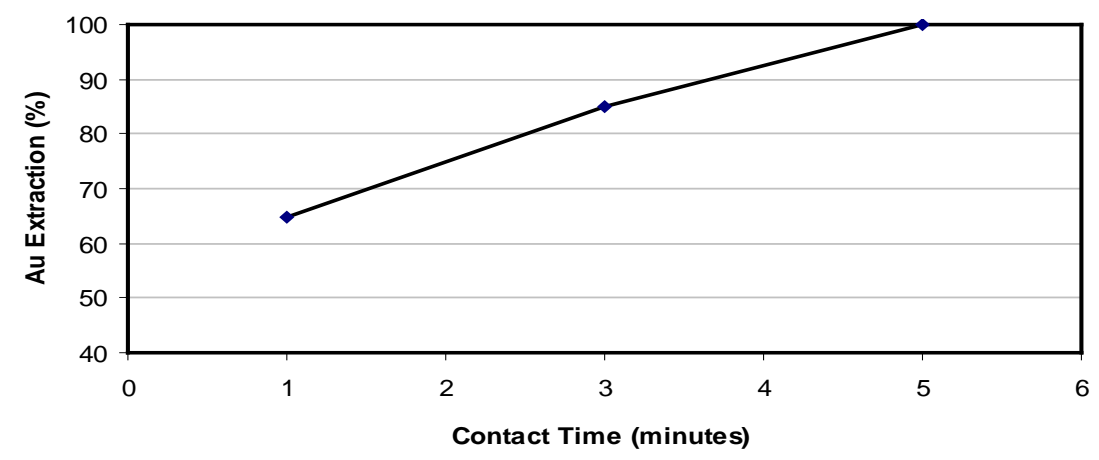

Figure 3. Effect of contact time on gold extraction.

Table 10. Statistical evaluations for gold determination by the present developed AAS method.

\begin{tabular}{cccccc}
\hline Sample & Au by Fire Assay $(\mathrm{ppm})$ & Au by AAS $(\mathrm{ppm})$ & Standard Deviation & Standard Error & $\%$ Error \\
\hline MA-1a & 21.7 & 22.5 & 1.05 & 0.608 & 2.5 \\
S1 & 4.9 & 4.96 & 0.14 & 0.081 & 1.6 \\
S3 & 1.2 & 1.18 & 0.03 & 0.017 & 1.4 \\
Pyrite & 3.6 & 3.44 & 0.19 & 0.113 & 3.0 \\
Serpentine & 0.7 & 0.686 & 0.017 & 0.01 & 1.5 \\
\hline
\end{tabular}

reached using MIBK as efficient extracting solvent were $3 \mathrm{M} \mathrm{HCl}$ extracting medium, A/O phase ratio of 5, 5 minutes contact time and 3 minutes settling time. The loaded extract was scrubbed with $0.1 \mathrm{M} \mathrm{HCl}$, and then gold was determined directly in the organic phase using FAAS. Statistical evaluation of the obtained results showed that the standard deviation values ranged from 0.017 - 1.03; the standard error ranged from 0.01 to 0.608 ; and the percentage error ranged from $1.4 \%$ to $3.0 \%$.

\section{Acknowledgements}

The authors were so grateful to Professor Doctor Ibrahim El katan, Nuclear Materials Authority, for his fruitful discussions and kind help in supplying some of the applied rock samples used in the studied developed method. Thanks goes also to Professor Doctor Gihad Saleh, Nuclear Materials Authority, for his kind supply of the other rock samples for completing the application work.

\section{References}

[1] Urucu, O.A., Yurtman, Z. and Kok Ye Timozlu, E. (2013) Cloud Point Preconcentration of Gold (III) and Determination by Flame Atomic Absorption Spectrometry. Indian Journal of Chemical Technology, 20, 106-110.

[2] Ramesh, S.L., Sunder Raju, P.V., Anjaiah, K.V., Ramavathi, M., Gnaneswara, R., Dasaram, B., Nirmal Charan, S., Suba Rao, D.V., Sarma, D.S., Ram Mohan, M. and Balaram, V. (2001) Determination of Gold in Rocks, Ores, and Other Geological Materials by Atomic Absorption Techniques. Atomic Spectroscopy, 22, 263-269.

[3] Knorre, H., Loroeseh, S.J., Steinheim H., Hanau, S.G., Stoll, M., Marjoss, S. and Ziegler, A. (1993) Process for Leaching Precious Metals with Hydrogen Peroxide. US Patent No. 5250272.

[4] Van Loon, J.C. and Barefoot, R.R. (1991) Determination of Precious Metals-Selected Instrumental Methods. John Wiley and Sons, New York.

[5] Greeonewald, T. (1969) Quantitative Determination of Gold in Solution by Solvent Extraction and Atomic Absorption Spectrometry. Analytical Chemistry, 41, 1012-1015. http://dx.doi.org/10.1021/ac60277a036

[6] Rubeska, I., Thomas, V.A., Baby, J.V. and Thomas, O.J. (1980) Interim Report CH-5 Mineral Exploration and Development in Kerala. UN Assisted Project, Trivandrum, 1-12.

[7] Tewari, R.K., Tarsekar, V.K. and Lokhande, M.B. (1990) Determination of Gold in Geological Materials by Flame Atomic Absorption Spectrometry at ppm and sub-ppm Levels by Coprecipitation with Mercury. Atomic Spectroscopy, 11, 125. 
[8] Benedetti, M.F., Dekersabiec A.M. and Boulegue, J. (1987) Determination of Gold in Twenty Geochemical Reference Samples by Flameless Atomic Absorption Spectrometry. Geostand Newsletters, 11,127. http://dx.doi.org/10.1111/j.1751-908X.1987.tb00016.x

[9] Yan, M., Wang, C., Cao, Q.X., Gu, T.X. and Chi, Q.H. (1995) Eleven Gold Geochemical Reference Samples (GAU 8-18). Geostand Newsletters, 19, 125-133. http://dx.doi.org/10.1111/j.1751-908X.1995.tb00157.x

[10] Balaram, V. and Anjaiah, K.V. (1997) Direct Estimation of Gold in Geological Samples by Inductively Coupled Plasma Mass Spectrometry. Journal of Indian Chemical Society, 74, 581-583.

[11] Barefoot, R.R. (1998) Determination of Precious Metals in Geological Materials by Inductively Coupled Plasma Mass Spectrometry. Journal of Analytical Atomic Spectrometry, 13, 1077-1084. http://dx.doi.org/10.1039/a803216e

[12] Elson, O.M. and Chatt, A. (1983) Determination of Gold in Silicate Rocks and Ores by Coprecipitation with Tellurium and Neutron Activation- $\gamma$-Spectrometry. Analytica Chimica Acta, 155, 305-310. http://dx.doi.org/10.1016/S0003-2670(00)85610-X

[13] Manikyamba, C., Naqvi, S.M. and Sawkar, R.H. (1997) Identification of Sandur Schist Belt as a Potential Gold Field. Current Science, 72, 515-518.

[14] Tindall, F.M. (1965) Silver and Gold Assay by Atomic Absorption Spectrometry: Perkin-Elmer Atomic Absorption. Atomic Absorption Newsletters, 4, 339-340.

[15] Tindall, F.M. (1966) Notes on Silver and Gold Assay by Atomic Absorption. Atomic Absorption Newsletters, 5, 140.

[16] Elmer, P. (1990) Analytical Methods for Atomic Absorption Spectrophotometry. GC-6.

[17] Sporea, A., Radulescu, R. and Petrescu, S. (2001) Determination of the Content of Gold and Silver in Geological Samples. Journal of Serbian Chemical Society, 66, 45-52.

[18] Ritcey, G.M. and Ashbrook, W.A. (1979) Solvent Extraction-Part II. Amsterdam, Elsevier.

[19] Wilkinson, W.D. (1962) Uranium Metallurgy Vol. II, Ch. 7. Interscience Publishers, New York.

[20] Stafilov, T. and Todorovski, T. (1987) Determination of Gold in Arsenic-Antimony Ore by Flameless Atomic Absorption Spectrometry. Atomic Spectroscopy, 8, 12-14.

[21] Pohl, P. and Zyrnicki, W. (2001) Study of Chemical Vapors Generation of Au, Pd and Pt by Inductively Coupled Plasma Atomic Emission Spectrometry. Journal of Analytical Atomic Spectrometry, 16, 1442-1445. http://dx.doi.org/10.1039/b105298p

[22] Elsaied, F.A., Farag, N.M., Fouad, H.K. and Shalaby, Z.M. (2009) Development of the Flame Atomic Absorption Spectroscopic Method for Beryllium Determination. Journal of Applied Sciences Research, 5, 499-504.

[23] Petrovic, N., Budelan, D., Cokic, S. and Nesic, B. (2001) The Determination of the Content of Gold and Silver in Geological Samples. Journal of Serbian Chemical Society, 66, 45.

[24] Sparrow, G.J. and Woodcock, J.T. (1995) Cyanide and Other Lixiviant Leaching Systems for Gold with some Practical Applications. Mineral Processing and Extractive Metallurgy Reviews: An International Journal, 14, 193-247. http://dx.doi.org/10.1080/08827509508914125

[25] Pyrzynska, K. (2005) Recent Developments in Determination of Gold by Atomic Absorption Spectrometry Techniques. Spectrochimica Acta Part B, 60, 1316-1322. http://dx.doi.org/10.1016/j.sab.2005.06.010

[26] Strong, B. and Murray-Smith, R. (1974) Determination of Gold in Copper Bearing Sulphide Ores and Metallurgical Flotation Products by Atomic Absorption Spectrometry. Talanta, 21, 1253-1258. http://dx.doi.org/10.1016/0039-9140(74)80146-3

[27] Shoemaker, R.S. (1990) Refractory Gold Ore Processing. Proceedings of Advances in Gold and Silver, Reno, 10-12 September 1990, 113-118.

[28] James, G.S. (1973) Optima. Anglo American Corporation Quarterly Review, 23, 99.

[29] Fishkova, N.L., Falkova, O.B. and Meshalkina R.D. (1972) Atomic-Absorption Determination of Gold in Ores and Estimation of Effect of Homogeneity of Its Distribution in Samples on Analysis Result. Journal of Analytical Chemistry, USSR, 27, 174.

[30] Almeida, M.F. (2001) Leaching of a Gold Bearing Partially Roasted Sulphide. Laboratory Scale Studies. Materials Research, 4, 305-314.

[31] Diamantatos, A. (1981) A Solvent-Extraction Scheme for the Determination of Platinum, Palladium, Rhodium, Iridium and Gold in Platiniferous Materials. Analytica Chimica Acta, 131, 53-62.

[32] Yokoyama, T., Yokota, T., Hayashi, S. and Izawa, E. (1996) Determination of Gold in Rock Samples by a Combination of Two-Stage Solvent Extraction and Graphite Furnace Atomic Absorption Spectrometry: The Problem of Iron Interference and Its Solution. Geochemical Journal, 30, 175-181. http://dx.doi.org/10.2343/geochemj.30.175

[33] Pyrzynska, K. (2005) Recent Developments in Determination of Gold by Atomic Absorption Techniques. Spectrochimica Acta Part B, 60, 1316-1322. http://dx.doi.org/10.1016/j.sab.2005.06.010 